\title{
Processes for Sustaining Energy in Noncertified Historic Buildings: A Case Study of Smith Plantation
}

\author{
Jacqueline Furcha Stephens, Hussein Faud Abaza \\ Construction Management Department, Kennesaw State University, Kennesaw, the United States
}

Email address:

Jstep109@kennesaw.edu (J. F. Stephens)

To cite this article:

Jacqueline Furcha Stephens, Hussein Faud Abaza. Processes for Sustaining Energy in Noncertified Historic Buildings: A Case Study of Smith Plantation. American Journal of Energy Engineering. Vol. 9, No. 3, 2021, pp. 60-67. doi: 10.11648/j.ajee.20210903.11

Received: July 3, 2021; Accepted: July 22, 2021; Published: August 11, 2021

\begin{abstract}
This paper addresses energy efficiency, indoor air quality, and water consumption in historic buildings. Building sustainability has become a worldwide issue from new construction to existing buildings. Historic buildings make up a large part of existing buildings throughout the world, making it essential that research is done to provide these buildings with sustainable options. The areas of special concerns in renovating historic buildings are improving indoor environmental quality, indoor air quality, water efficiency, and energy efficiency while maintaining the historical value of these buildings. This paper presents a case study of the Smith Plantation in Metro Atlanta, Georgia. The study includes 1) field verification and existing condition assessment of the thermal comfort, energy consumption, and indoor air quality. 2) Building information modeling was used to simulate the energy performance of the buildings as well as determining the $\mathrm{CO}_{2}$ footprint. These models were calibrated and verified against field readings. 3) the simulation models were used to generate design and renovation alternatives to improve the energy efficiency of these buildings as well as reducing the $\mathrm{CO}_{2}$ footprint without impacting the originality of these buildings. This study will provide general design guidelines and renovation options for historic buildings to reduce energy consumption and creating a smaller carbon footprint while maintaining the authenticity of the buildings.
\end{abstract}

Keywords: Indoor Air Quality, Historic Buildings, Energy Efficiency, Energy Modeling, Sustainability, Building Information Modeling

\section{Introduction}

With approximately 1.4 million properties on the National Register of Historic Places [1] of those, there are about 67,000 individual historic buildings [2] when including historic districts, the number of historic buildings increases significantly. In the state of Georgia, there are 2,300 historic homes and 2,000 historic districts [3]. In 2018, the registry added 510 buildings and 304 districts, fourteen of the buildings and seventeen of the districts were located in Georgia [1]. Criteria for being placed on the national registry are the building's age, must be a minimum of fifty years old, and significance to history. Determining historical significance is done by the connection of the structures to events and people, as well as architectural importance [4]. An event that contributed to the advancement of a city, state, nation, or combination thereof is one way of interpreting an event as historic. Along with the building's age and significance to history, a building must retain the architectural features equivalent to the established era of historical significance [4]. The inclusion of historic buildings in the sustainable movement is apparent based on the registry numbers alone.

The purpose of this research is to demonstrate that a historic building can be made sustainable without ruining the authenticity of the original structure. This study will look at the indoor air quality, heating and cooling loads, and the building's components to determine changes required to create a more sustainable building. They will be examined based on the need to stay authentic to the historic aspects of the building. With codes and standards becoming more sustainably stringent for both new and existing buildings it is imperative that historic buildings are included in these requirements. Research of this sort is essential because of the astounding number of historic buildings throughout the United States, as seen in the National Register of Historic Places. 
When looking at sustaining historic buildings each building needs to be looked at individually to determine the inherently sustainable methods taken at the time of construction because alteration of those methods could affect the authenticity of the building [5]. Problems with modern upgrades to these buildings through the methods used for controlling moisture and standards for modern insulation and energy-efficient HVAC systems is that they can cause more damage than they fix [6]. Buildings built before World War II, before air-conditioning systems [7], were designed based on the climatic conditions of the site [8]. They were intended to maximize the natural resources for heating, lighting, and ventilation, creating a well-developed sense of physical comfort [8]. Heating lighting historic buildings was done through window placement and fireplaces whereas cooling was accomplished by window placement to create breezes, shutters and shades, awnings, and vestibules. With the conversion of many historic buildings into museums, there is the need to provide heating, cooling, and ventilation systems for human comfort. There is a lack of concern for energy efficiency and indoor air quality with the installation of these systems. These systems need to be considered carefully because the chemicals allowed into the building can affect the visitors and the artifacts within.

This research will be a case study of the Archibald Smith Plantation located in Roswell, Georgia, United States and is on the National Register of Historic Places. Currently, there are ten original outbuildings located on the site the springhouse, guest house, caretaker's cottage, smokehouse, covered well, barn, necessary house, servant's house, and corn crib. This study will include four of these buildings the plantation site, the plantation house, caretaker's cottage, guest house, and carriage house. The oldest building on the site, built-in 1844, is the caretaker's house; this is where the Smith family lived during the construction of the main house. It has a wood shake roof and clapboard siding (resided in 1940) [9]. When a massive tree fell on it in 1996, it was rebuilt using many of the original materials. A heating, ventilation, and air conditioning (HVAC) unit was added to the northeastern corner of the cottage for the protection of the artifacts because this is where they now store the archives [9]. The plantation house was completed circa 1845 in the Greek Revival style and resided until 1940 [9]. The next structure used in this study is the guest house, which built-in 1850. This building has the original hewn log floor joists, clapboard siding, and asphalt shingles install in 1940 [9]. The HVAC unit's location for this building is on the northern side of the building [9]. The Smith Plantation is currently using this building for the office of the plantation. The addition of the carriage house came about in 1845 [9].

The original house is a two-story structure over a crawl space with a gable roof structure and front porch at the firstfloor level. The structure of the main house consists of $2 \times 4$ wood studs with no insulation between the studs. They are covered with stucco on the inside and clapboard wood siding on the outside. It has single-pane wood windows and uninsulated wood doors. The roof consists of wood shingles with attic space and a stucco ceiling. There are hardwood wood floors throughout the house; wallpapered rooms with interior trim that has historical value. The house also maintained its historical furniture and many original pieces of house equipment. Residences personal items are exhibited in the house. Thus, weather control is essential to maintain these items. The original plantation house as it was in 1900, is shown in Figure 1.

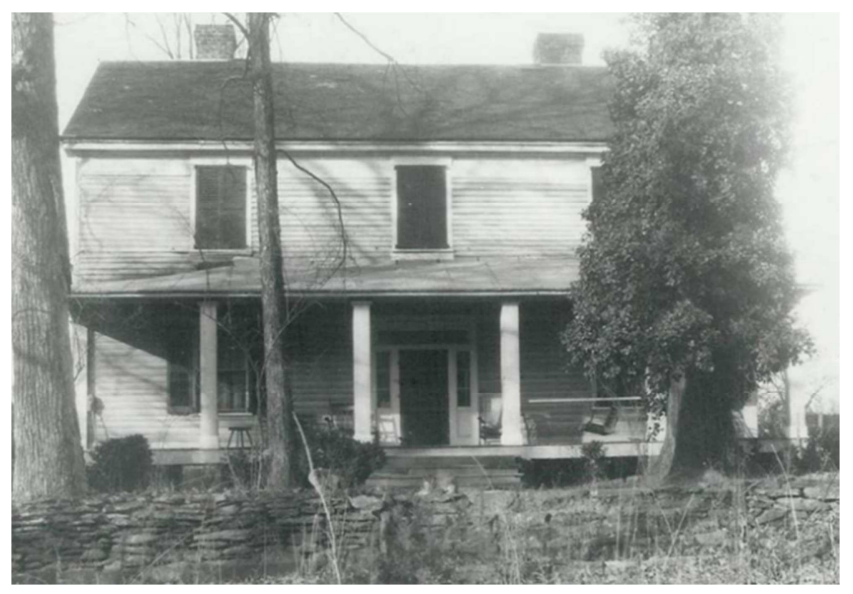

Figure 1. Smith house in 1900. source: city of roswell. The jaeger company, archibald smith plantation home: master plan report, roswell, 2009.

In 1950, the plantation house went through a major renovation, during the renovation larger windows replaced the original ones, which are still single-paned, and the porch was extended and raised to the second-floor level. The windows are, and the exterior doors are also uninsulated wood doors. Currently, it is climate controlled through a central HVAC system for summer and winter. Originally the house had four fireplaces and a wood oven in the kitchen used for heating; these fireplaces are not currently in use. In addition to the HVAC system, there are three dehumidifiers. They are on the first and the second floors and used to control the relative humidity to protect the artifacts in the house. The house currently looks like the picture in Figure 2.

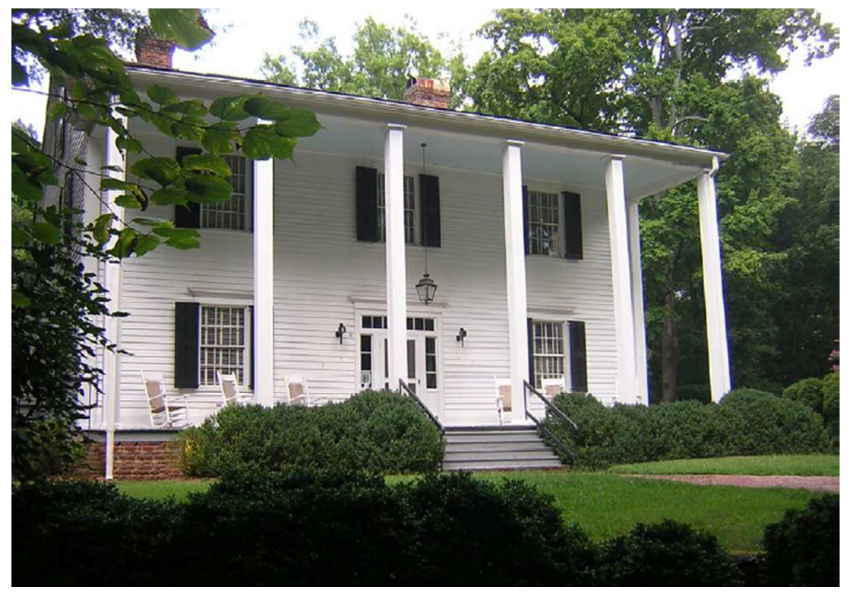

Figure 2. Smith house as it is currently. Source: city of roswell. The jaeger company, archibald smith plantation home: master plan report, roswell, 2009 . 


\section{Methodology}

As a means of ascertaining renovation options that will aid in the reduction of energy consumption and create a smaller carbon footprint without affecting the authenticity of the buildings the processes used were extensive interviews with the maintenance team of the facility, building information models and field readings. Interviews were used to determine the existing characteristics of the facility and any improvements made to the building that might affect energy efficiency. The equipment used for the field readings was the QUESTemp 46/Thermal Environment Monitor, Ion Science ProCheck Tiger, and Met One Instruments GT-321 Particle Monitor. The QUESTemp 46/Thermal Environment Monitor tested for the wet bulb and dry bulb temperatures, flow, and relative humidity through high-quality heat stress testing [10]. Parts per million of carbon dioxide $\left(\mathrm{CO}_{2}\right)$, alkane, benzene $\left(\mathrm{C}_{6} \mathrm{H}_{6}\right)$, and nitrogen dioxide $\left(\mathrm{NO}_{2}\right)$ were found using the Ion Science ProCheck Tiger. Biological and nonbiological airborne particles sized between 0.3 to 5.0 nanometers was done using the Met One Instruments GT-321 Particle Monitor.

Along with the field testing an energy simulation using the Energy-Plus energy analysis tool in Revit was run. The United States Department of Energy (DOE) developed Energy-Plus to calculate cooling, heating, ventilation, and artificial and natural lighting. This study did not use the lighting feature. Energy-Plus has the capability of predicting the comfort levels when the existing HVAC system cannot meet the heating/cooling demands. It also accounts for indoor surface temperature when calculating comfort level. The software can also calculate heat and moisture transfer through the building envelop [11]. These features make Energy-Plus suitable to simulate historical buildings. The simulation used a model of the plantation house and Roswell city weather data to determine the energy efficiency of the plantation house.

\subsection{Field Testing}

To determine the actual building performance and to calibrate the building simulation field data was collected inside each of the four buildings and outside. Data collected included wet bulb and dry bulb temperatures, relative humidity, flow, carbon dioxide $\left(\mathrm{CO}_{2}\right)$, alkane, benzene $\left(\mathrm{C}_{6} \mathrm{H}_{6}\right)$, nitrogen dioxide $\left(\mathrm{NO}_{2}\right)$, and airborne particles sized between 0.3 to 5.0 nanometers.

Table 1 shows the wet bulb, dry bulb, relative humidity, and flow for the buildings. Temperature is a concern when historical artifacts are taken into account because an increase in temperature can cause deterioration in the artifacts [12]. Fluctuations in dry bulb temperature can affect the relative humidity; the optimal temperature range is $20-22^{\circ} \mathrm{C}\left( \pm 2-3^{\circ} \mathrm{F}\right)$ [12]. All dry bulb temperatures are too high in the buildings with artifacts; this will need to be corrected to protect the artifacts.

Relative humidity needs to stay in a constant range of $50 \%-60 \%$ for mixed collections like the ones in the plantation buildings [12]. Only the barn and the downstairs front room of the house come within that range.

Table 1. Temperature, Relative Humidity, And Flow for The Buildings.

\begin{tabular}{|c|c|c|c|c|}
\hline & WB & DB & RH & FLOW \\
\hline OFFICE & $17.5^{\circ} \mathrm{C}$ & $27.1^{\circ} \mathrm{C}$ & $38.8 \%$ & $4.0 \mathrm{~m} / \mathrm{s}$ \\
\hline BARN & $20.4^{\circ} \mathrm{C}$ & $29^{\circ} \mathrm{C}$ & $54.6 \%$ & $4.0 \mathrm{~m} / \mathrm{s}$ \\
\hline ARCHIVES & $15.5^{\circ} \mathrm{C}$ & $25.6^{\circ} \mathrm{C}$ & $33.3 \%$ & $4.0 \mathrm{~m} / \mathrm{s}$ \\
\hline HOUSE UPSTAIRS HALL & $17.5^{\circ} \mathrm{C}$ & $25.4^{\circ} \mathrm{C}$ & $46.7 \%$ & $3.9 \mathrm{~m} / \mathrm{s}$ \\
\hline HOUSE UPSTAIRS BACK BEDROOM & $17.2^{\circ} \mathrm{C}$ & $24.4^{\circ} \mathrm{C}$ & $47.5 \%$ & $3.9 \mathrm{~m} / \mathrm{s}$ \\
\hline HOUSE DOWNSTAIRS BACK ROOM & $15^{\circ} \mathrm{C}$ & $22^{\circ} \mathrm{C}$ & $46.2 \%$ & $4.0 \mathrm{~m} / \mathrm{s}$ \\
\hline HOUSE DOWNSTAIRS FRONT ROOM & $19.6^{\circ} \mathrm{C}$ & $25.8^{\circ} \mathrm{C}$ & $57.3 \%$ & $4.0 \mathrm{~m} / \mathrm{s}$ \\
\hline OUTSIDE & $19.6^{\circ} \mathrm{C}$ & $24.9^{\circ} \mathrm{C}$ & $62.7 \%$ & $4.0 \mathrm{~m} / \mathrm{s}$ \\
\hline
\end{tabular}

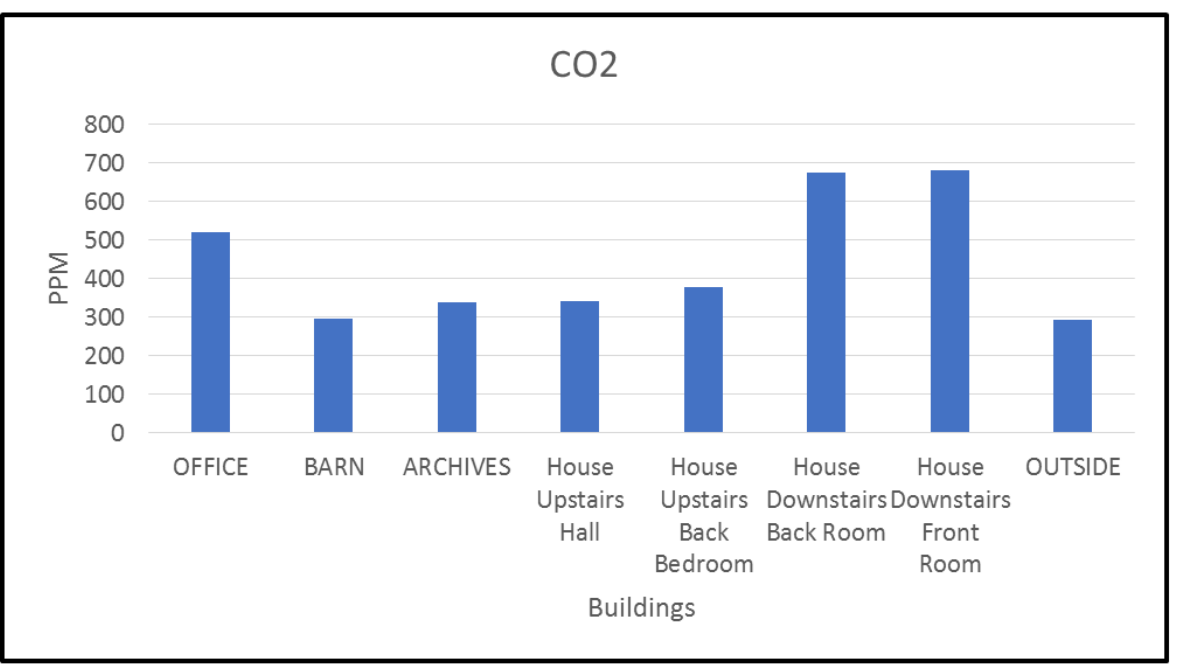

Figure 3. $\mathrm{CO}_{2}$ Levels In The Buildings. 
Per Figure 3: $\mathrm{CO}_{2}$ levels in the buildings and outside show the office and downstairs back, and front rooms of the house have levels much higher than outside. The office is about 250 ppm higher than the 293 ppm outside, and the downstairs of the house is about 380 ppm higher. The outside measurement of $293 \mathrm{ppm}$ is within the normal range for outside. Even though the levels for the office and downstairs of the house are much higher than the outside, they are still within a safe range [13]. An increase in $\mathrm{CO}_{2}$ levels may be from the number of visitors in the house and the number of employees in the office. All alkane and benzene levels are well under safe ranges. Figure 4 shows the levels of alkane and benzene in the four buildings and the outside.

Based on the Environmental Protection Agency's Air Quality
Guide for Nitrogen Dioxide safe levels, the barn and the downstairs back room are in the very unhealthy range. With the levels being in an unhealthy range means that people with lung disease, like asthma, and children and the elderly should avoid being in those buildings. The downstairs front room, outside, and upstairs back bedroom are just slightly over the threshold for being very unhealthy. All other buildings are well above the range [14]. Figure 5 shows the nitrogen dioxide levels.

Table 2 shows the results of the particulate matter testing. Particulate matter found in house museums wanting to protect their artifacts can discolor pigments in paintings and corrode metal objects, distortion and effect shear stresses in furniture and increases the degradation rate of paper products and textiles [15-17].

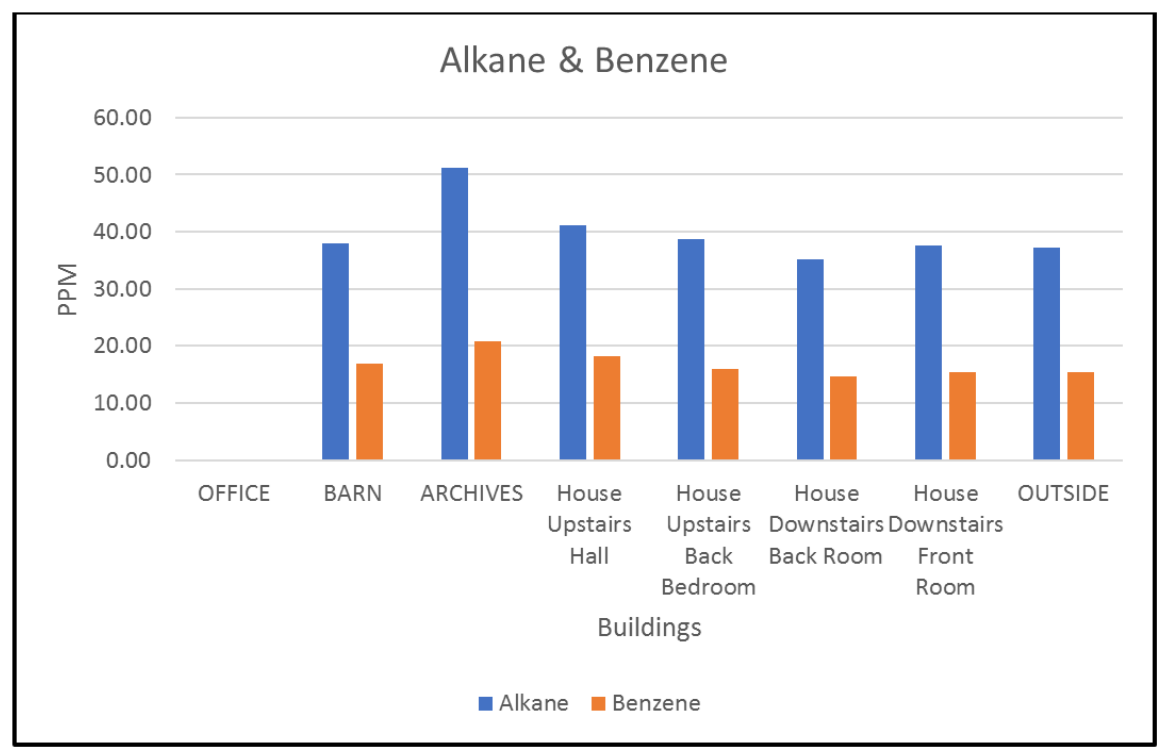

Figure 4. Alkane \& benzene levels in the buildings.

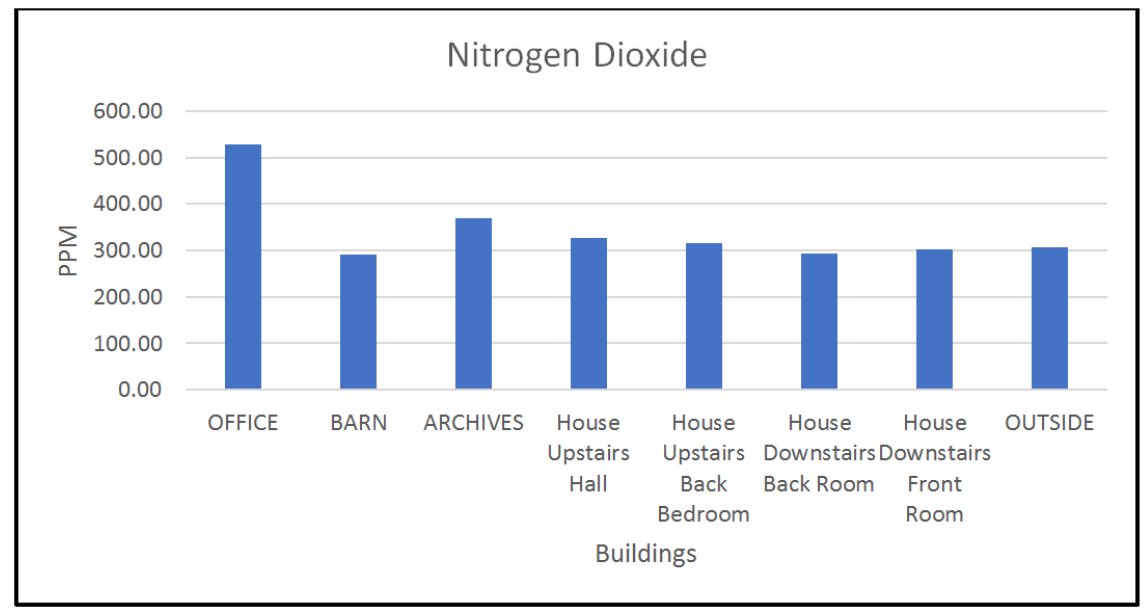

Figure 5. Nitrogen dioxide levels in the buildings.

\subsection{Building Simulation}

The building model was simulated based on the information and plans gathered from the facility manager. To do an in-depth analysis of the house's building components, it would require destructive testing, which would defeat the idea of maintaining the authenticity of the building. Calibration was done to match the actual performance of the plantation house. Figure 6 shows the completed Revit model. 


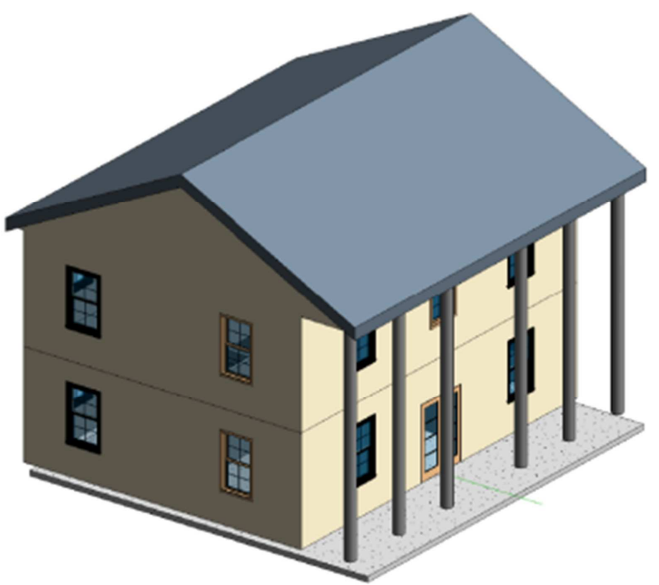

Figure 6. Revit model of the plantation house.

Single-paned glass with $90 \%$ SHGC and a U-value of 1.05 were the default for the windows in the simulation model. The house was considered "loose" with an infiltration rate of 1.15 Air Change per Hour (ACH). Field observations were the basis for choosing this infiltration rate. Blower Door testing was not possible because that will interrupt the house function as a historical attraction. The simulation model was calibrated to match the actual performance of the plantation house. The field readings of the indoor and outdoor temperature and $\mathrm{RH}$, as well as the actual energy consumption, were used to calibrate the simulation model. Figure 7 shows the completed simulation model.

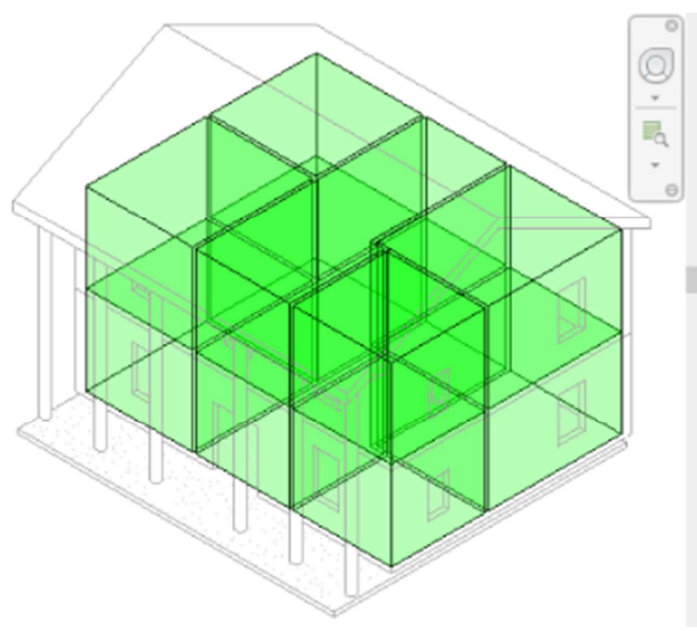

Figure 7. Building simulation model of the house.

\section{Results}

The simulation results showed that the maximum cooling load capacity is $44,500 \mathrm{Btu} / \mathrm{h}$, and the peak heating load is $37,900 \mathrm{Btu} / \mathrm{h}$ (Table 2). Based on the cooling load density of the plantation, Table 3 shows that it is similar to that of buildings built in the Atlanta area before 1980 [17].

Table 2. Results from Field Testing for Particulate Matter.

\begin{tabular}{|c|c|c|c|c|c|}
\hline & $.3 \mu$ & $.5 \mu$ & $1.0 \mu$ & $2.0 \mu$ & $5.0 \mu$ \\
\hline Office & $1,349,846$ & 90,468 & 11,340 & 2,628 & 486 \\
\hline Barn & $2,155,293$ & 181,512 & 22,203 & 8,676 & 1,008 \\
\hline Archive & $1,758,879$ & 120,620 & 12,069 & 4,545 & 548 \\
\hline House Upstairs Hall & $1,478,448$ & 83,052 & 8,829 & 6,174 & 711 \\
\hline House Upstairs Back Bedroom & $1,601,451$ & 88,803 & 11,596 & 5,607 & 712 \\
\hline House Downstairs Backroom & $1,197,369$ & 64,512 & 9,279 & 4,428 & 819 \\
\hline
\end{tabular}

Table 3. Results of Energy-Plus Simulation.

\begin{tabular}{ll}
\hline INPUTS & Single-Family \\
\hline Building Type & 1,727 \\
\hline Area (SF) & $17,268.31$ \\
Volume (CF) & \\
CALCULATED RESULTS & $44,479.8$ \\
Peak Cooling Total Load (Btu/h) & August 3:00 PM \\
Peak Cooling Month and Hour & $38,898.5$ \\
Peak Cooling Sensible Load (Btu/h) & $5,581.4$ \\
Peak Cooling Latent Load (Btu/h) & $44,479.8$ \\
Maximum Cooling Capacity (Btu/h) & 1,315 \\
Peak Cooling Airflow (CFM) & $37,857.39$ \\
Peak Heating Load (Btu/h) & 1,283 \\
Peak Heating Airflow (CFM) & \\
CHECKSUMS & 25.76 \\
Cooling Load Density (Btu/h $\left.\cdot \mathrm{ft}^{2}\right)$ & 0.76 \\
Cooling Flow Density (CFM/SF) & 354.81 \\
Cooling Flow/Load (SF/ton) & 465.87 \\
Cooling Area/Load (SF/ton) & 21.92 \\
Heating Load Density (Btu/h $\cdot \mathrm{ft}^{2}$ ) & 0.74 \\
Heating Flow Density (CFM/SF) & \\
\hline
\end{tabular}


Table 4. Results of Heating and Cooling Load Simulation.

\begin{tabular}{|c|c|c|c|c|}
\hline \multirow{2}{*}{ Location } & \multirow{2}{*}{ 90.1-2004 Climate Zone } & Pre-1980 & Post-1980 & New Construction \\
\hline & & Btu/h $\cdot \mathbf{f t}^{2}$ & Btu/h $\cdot \mathbf{f t}^{2}$ & Btu/h$\cdot \mathbf{f t}^{2}$ \\
\hline Miami, FL & $1 \mathrm{~A}$ & 0.230 & 1.000 & 0.580 \\
\hline Houston, TX & $2 \mathrm{~A}$ & 0.230 & 0.340 & 0.580 \\
\hline Atlanta, GA & $3 \mathrm{~A}$ & 0.225 & 0.290 & 0.151 \\
\hline Los Angeles, CA & 3B-CA & 0.230 & 0.290 & 0.151 \\
\hline Los Vegas, NV & 3B-other & 0.230 & 0.290 & 0.580 \\
\hline Baltimore, MD & $4 \mathrm{~A}$ & 0.178 & 0.120 & 0.580 \\
\hline Seattle, WA & $4 \mathrm{C}$ & 0.175 & 0.100 & 0.151 \\
\hline Chicago, IL & $5 \mathrm{~A}$ & 0.156 & 0.100 & 0.151 \\
\hline Denver, CO & $5 \mathrm{~B}$ & 0.161 & 0.140 & 0.151 \\
\hline Minneapolis, MN & $6 \mathrm{~A}$ & 0.145 & 0.071 & 0.123 \\
\hline Helena, MT & $6 \mathrm{~B}$ & 0.145 & 0.079 & 0.123 \\
\hline Duluth, MN & 7 & 0.136 & 0.061 & 0.123 \\
\hline Fairbanks, AK & 8 & 0.125 & 0.047 & 0.104 \\
\hline
\end{tabular}

Table 5. Results of Heating and Cooling Load Simulation.

\begin{tabular}{llll}
\hline \multirow{2}{*}{ Components } & Cooling & Heating \\
\cline { 2 - 4 } & Loads (Btu/h) & Percentage of Total & Loads (Btu/h) \\
\hline Wall & $9,300.4$ & $20.91 \%$ & $12,822.0$ \\
Window & $16,908.9$ & $38.01 \%$ & $5,203.4$ \\
Door & $1,322.5$ & $2.97 \%$ & $1,697.0$ \\
Roof & $3,024.5$ & $6.8 \%$ & $2,235.7$ \\
Infiltration & $5,666.8$ & $12.74 \%$ & $9,979.0$ \\
Lighting & $1,775.3$ & $3.98 \%$ & \\
Power & $1,775.3$ & $3.98 \%$ & \\
People & 202.7 & $0.46 \%$ & $5.48 \%$ \\
Fan Heat & 792.0 & $1.78 \%$ & $26.36 \%$ \\
Total & $40,768.4$ & $100 \%$ & $31,937.1$ \\
\hline
\end{tabular}

The simulation model was set to maintain the indoor temperature to no less than $68^{\circ} \mathrm{F}$ in winter and $76^{\circ} \mathrm{F}$ in summer $\left(20^{\circ} \mathrm{C}-24.4^{\circ} \mathrm{C}\right)$ and maintain relative humidity between $50 \%-70 \%$. However, the field readings showed that the house indoor air temperature of the upstairs floor in the house reached $25.4^{\circ} \mathrm{C}\left(78^{\circ} \mathrm{F}\right)$ and the relative humidity at $46.7 \%$. The lower relative humidity can is due to their use of dehumidifiers on the first and second floor.

Simulation results also showed that the windows and walls contributed to approximately $59 \%$ of the cooling load and $47 \%$ of the heating load. Since they have historical value replacing the windows would jeopardize the value of the plantation house. Infiltration contributed to approximately $13 \%$ of the cooling load and $26 \%$ of the heating load while the roof contributed to $7 \%$ of the cooling load and $6 \%$ of the heating load. Table 4 shows the results of the heating and cooling simulation.

\section{Solutions}

The addition of a building management system along with programmable thermostats will improve the problem of controlling the relative humidity and temperature $[19,20]$. These systems have the capability of maintaining temperature setpoints; this would help the temperature stay within the $20-22^{\circ} \mathrm{C}$ range. Dehumidifiers should not be running; they are taking too much humidity out of the air, which is keeping the relative humidity too low. They need to get the range back up to $50 \%-60 \%$ relative humidity.

To reduce the levels of particulate matter and chemicals in the air, mechanical or carbon filters should be installed. The carbon filters will sustain sulfur oxides and remove ozone [21]. To counter the formation of nitric acid and outdoor pollutants use activated charcoal in its pure form or an alkaline impregnation. Other methods would be the use of silica gels, zeolites, or permanganate-impregnated alumina [22].

The first changes that would be recommended to reduce infiltration would be to add R-60 insulation in the attic while keeping the existing ventilation, put moistureresistant polystyrene lining in the crawl space and insulate the crawl space [23]. When adding insulation, it is important to remember the structure's original ability to tolerate moisture and its need to maintain its breathability [23]. Along with the addition of attic insulation, the doors and windows should have weather stripping. The best option is to use draft-proof interlocking zinc, bronze, or stainless-steel weather stripping [20]. The weatherstripping around the windows will need to have weep holes on the bottom to drain or vent any condensation [20]. Siding can be caulked to fill cracks that might allow air to enter the house. The single-paned glass windows need to be changed to double-paned to increase energy savings and reduce heating and cooling loss. Changing the panes in a way that will maintain their historical integrity is done by keeping the wood frame and just changing out the panes of glass. Along with this an air barrier gasket can be added to the window frame to reduce infiltration. These measures will also help in recusing moisture transfer through the structure, which will help in maintaining the house's structural integrity and reduce aging. 
After rerunning the simulation using the recommended changes, there was a reduction in the cooling load of 80,000 Btu and 13,300 Btu in the heating load. Thus, resulting in a $20 \%$ reduction in the cooling load and a $35 \%$ reduction in the heating load. Based on Table 6, the cooling load is approximately $52 \%$ and the heating load about $21 \%$. There is an overall reduction in the cooling load of 5,186.4 Btu and the heating load 7,315.1 Btu.

Table 6. Simulation Results After Recommend Changes.

\begin{tabular}{|c|c|c|c|c|}
\hline \multirow{2}{*}{ Components } & \multicolumn{2}{|l|}{ Cooling } & \multicolumn{2}{|l|}{ Heating } \\
\hline & Loads (Btu/h) & Percentage of Total & Loads (Btu/h) & Percentage of Total \\
\hline Wall & $4,885.4$ & $13.73 \%$ & $7,920.6$ & $32.17 \%$ \\
\hline Window & $18,641.1$ & $52.39 \%$ & $5,203.4$ & $21.13 \%$ \\
\hline Door & $1,322.5$ & $2.97 \%$ & $1,697.0$ & $4.48 \%$ \\
\hline Roof & $1,755.5$ & $4.93 \%$ & $1,385.6$ & $5.63 \%$ \\
\hline Infiltration & $1,143.8$ & $3.21 \%$ & $2,494.8$ & $10.13 \%$ \\
\hline Lighting & $1,775.3$ & $4.99 \%$ & & \\
\hline Power & $1,775.3$ & $4.99 \%$ & & \\
\hline People & 144.0 & $0.40 \%$ & & \\
\hline Fan Heat & 633.1 & $1.86 \%$ & & \\
\hline Total & $35,582.0$ & $100 \%$ & $24,622.0$ & $100 \%$ \\
\hline
\end{tabular}

\section{Conclusion}

This research addressed improving energy efficiency in historic buildings without ruining their authenticity. The Archibald Smith Plantation in Roswell, Georgia, was the focus of this study. Energy-Plus was used to simulate the existing condition of the plantation house and exterior buildings using data collected from the facility manager and the field testing results. Data was collected using QUESTemp 46/Thermal Environment Monitor, Ion Science ProCheck Tiger, and Met One Instruments GT321 Particle Monitor. A building information model was created in Revit and Energy-Plus Simulation was applied Based on the results of the Energy-Plus simulation it was determined that the cooling load density is similar to Atlanta area buildings built before 1980. Simulation results also showed the windows and walls affected the cooling and heating loads along with some contribution from the roof. Based on the results changes were recommended that might improve the heating and cooling loads.

A new simulation was run with the recommended changes and it was compared to the original baseline simulation and ascertained the changes that would improve energy efficiency. The house performance cooling load could be reduced by $20 \%$ and the heating load by $40 \%$ through the addition of roof and crawl space insulation and weather stripping. None of the measures recommended would affect the authenticity of the building. The second simulation did not include the recommendation to change the single-paned glass to double; this would have increased the reduction in the heating and cooling loads. The study demonstrated that the Archibald Smith Plantation would be able to reduce their energy consumption and better protect their artifacts from damage due to improper temperatures and relative humidity.

\section{References}

[1] National Park Service, National Register Database and Research - National Register of Historic Places (U.S. National Park Service), (2018). https://www.nps.gov/subjects/nationalregister/databaseresearch.htm (accessed December 15, 2018).

[2] American Dreams Inc., National Register of Historical Places - GEORGIA (GA), (n.d.). https://nationalregisterofhistoricplaces.com/ga/state.html\#pick em (accessed December 15, 2018).

[3] S. Cherry-Farmer MHP, personal communication, (2019).

[4] National Park Service US Department of Interior, How to List a Property - National Register of Historic Places (U.S. National Park Service), (2018). https://www.nps.gov/subjects/nationalregister/how-to-list-aproperty.htm (accessed December 17, 2018).

[5] B. Rohdin, Patrik; Daleeski, Mariusz; Moshfegh, Combining a survey approach and energy and indoor environment auditing in historic buildings, J. Eng. Des. Technol. 14 (2016) 182196. doi: 10.1108/JEDT-06-2013-0042.

[6] H. R. Trechsel, M. T. Bomberg, S. C. Park, Moisture in Historic Buildings and Preservation Guidance, Moisture Control Build. Key Factor Mold Prev. Ed. (2009) 442-442-21. doi: 10.1520/MNL11562M.

[7] A. Green, Air Conditioning History, Facts \&amp; Overview of Air Conditioners, Pop. Mech. (2015). https://www.popularmechanics.com/home/how-to/a7951/abrief-history-of-air-conditioning-10720229/.

[8] B. M. Smith AIA, Preservation Brief: Conserving energy in historic buildings, Natl. Park Serv. Br. (n.d.). Retrieved June 8, 2019, from http://www.oldhouseweb.com/how-toadvice/hvac-and-insulation/preservation-brief-conservingenergy-in-historic-buildings.shtml (accessed June 8, 2019).

[9] City of Roswell. The Jaeger Company, Archibald Smith Plantation Home: Master Plan Report, Roswell, 2009. 
[10] TSI Quest. (n.d.). Questemp Heat Stress Monitors Models 44 and 46 User Manual.

[11] DOE, 2019; “ EnergyPlus” EnergyPlus is funded by the U.S. Department of Energy's (DOE) Building Technologies Office (BTO), and managed by the National Renewable Energy Laboratory (NREL). Retrieved August 16, 2019, from https://energyplus.net.

[12] What are safe levels of $\mathrm{CO}$ and $\mathrm{CO}_{2}$ in rooms? Kane International Limited, (n.d.). Retrieved August 17, 2019, from https://www.kane.co.uk/knowledge-centre/what-are-safelevels-of-co-and-co2-in-rooms.

[13] U.S. EPA, Air Quality Guide for Nitrogen Dioxide, EPA456/F-11-003, n.d. www.enviroflash.info (accessed August 17, 2019).

[14] W. Anaf, L. Bencs, R. Van Grieken, K. Janssens, K. De Wael, Indoor particulate matter in four Belgian heritage sites: Case studies on the deposition of dark-colored and hygroscopic particles, Sci. Total Environ. 506-507 (2015) 361-368. doi: 10.1016/j.scitotenv.2014.11.018.

[15] J. Grau-Bové, B. Budič, I. K. Cigić, D. Thickett, S. Signorello, M. Strlič, The effect of particulate matter on paper degradation, Herit. Sci. 4 (2016). doi: 10.1186/s40494-0160071-8.

[16] T. Padfield, The Role of Absorbent Building Materials in Moderating Changes of Relative Humidity, 1998, The Technical University of Denmark. Retrieved on August 17, 2019 from https://conservationphysics.org/phd/chla.pdf.

[17] U.S. Department of Energy "Commercial Reference Building Models of the National Building Stock," Technical Report, February 2011.

[18] R. Ruparathna, K. Hewage, R. Sadiq, Improving the energy efficiency of the existing building stock: A critical review of commercial and institutional buildings, 2015, Renewable and Sustainable Energy Reviews. Retrieved on June 16, 2018, from

http://eds.a.ebscohost.com.proxy.kennesaw.edu/eds/detail/deta il?vid=1\&sid=9ecbf86e-7d2a-4197-ba68bc1f40c200e $5 \% 40$ sdc-v-

sessmgr02\&bdata $=$ JnNpdGU9ZWRzLWxpdmUmc2NvcGU9 c210ZQ\%3d\%3d\#db=edsgao\&AN=edsgcl.521982496.
[19] A. Ball, G. Paxton, The Guidelines for Improving Energy Efficiency in Historic Buildings, 2012, Maine Preservation. Retrieved on April 17, 2018 from https://static1.squarespace.com/static/56b74bc427d4bd8d3cff 12f6/t/578cdf9546c3c4caeed188d7/1468850074429/EnergyEf fientMaine.pdf.

[20] G. Pavlogeorgatos, Environmental parameters in museums, Build. Environ. 38 (2003) 1457-1462. doi: 10.1016/S03601323(03)00113-6.

[21] A. Cavicchioli, R. Orsini, C. De Souza, G. R. Reis, A. Fornaro, Indoor Ozone and Nitrogen Dioxide Concentrtion in Two Museums of the Sao Paulo Megacity - Brazil, (2013) 113-122. Retrieved on January 26, 2019 from www.ePRESERVATIONScience.org.

[22] WBDG Historic Preservation Subcommittee, Updating Building Systems Appropriately, 2017. Retrieved on November 10, 2018 from http://www.wbdg.org/designobjectives/historic-preservation/update-building-systemsappropriately.

\section{Biography}

Jacqueline Furcha Stephens taught construction management at Westwood College until 2016 when she became an Assistant Professor at Kennesaw State University in Marietta, Georgia. She is currently working on her Ph. D. in Technology Management, specializing in Construction Management. Her interests are in historical building preservation and sustainability.

Hussein Faud Abaza, Ph.D. obtained his Ph. D. degree from the College of Architecture at Virginia Tech in 2002. He has more than 15 years of experience in the design and construction field, and more than 16 years of teaching experience. Dr. Abaza designed and built several super energy-efficient projects of which were on the TV news. He also worked as a designer, construction company owner, Architectural Designer, and project engineer. Dr. Abaza also obtained more than $\$ 3$ million of research, service, and US government consultation grants, and published three books, a software application, and more than 36 refereed publications. 